Journal of Maternal and Child Health (2019), 4(3): 146-157

https://doi.org/10.26911/thejmch.2019.04.03.02

\title{
Path Analysis on Factors Affecting the Choice of Female Surgical Contraceptive Method in Kendal, Central Java
}

\author{
Ainul Maghfiroh'), Uki Retno Budihastuti²), Ismi Dwi Astuti Nurhaeni3) \\ 1)Masters Program in Public Health, Universitas Sebelas Maret \\ 2)Department of Obstetrics and Gynecology, Dr. Moewardi Hospital, Surakarta \\ 3)Faculty of Social and Politic Science, Universitas Sebelas Maret
}

\begin{abstract}
Background: Indonesia is one of the developing countries with a high rate of population growth. The government established a Family Planning program in overcoming this problem with effective use of the female surgery contraception. This study aimed to analyze the determinants of female surgery contraceptive method using path analysis model.

Subject and method: A retrospective case control study was conducted in Kendal, Central Java. A sample of 200 women was selected for this study by fixed diseases sampling. The dependent variable was the choice of female surgery contraceptive method. The independent variables were age, education, number of children alive, employment, knowledge, attitude, self-efficacy, husband support, and perception of gender equality. The data were collected by questionnaire and analyzed by path analysis.

Results: The choice of female surgery contraception method was directly and positively associated with good knowledge $(b=1.91 ; 95 \% \mathrm{CI}=0.80$ to $3.02 ; \mathrm{p}=0.001)$, positive attitude $(b=1.56 ; 95 \%$ $\mathrm{CI}=0.45$ to $2.66 ; \mathrm{p}=0.006)$, good gender equality perception $(\mathrm{b}=1.25 ; 95 \% \mathrm{CI}=0.18$ to $2.32 ; \mathrm{p}=$ 0.021), high self efficacy $(b=1.61 ; 95 \% \mathrm{CI}=0.48$ to $2.74 ; \mathrm{p}=0.005)$, high education $(\mathrm{b}=1.18 ; 95 \%$ $\mathrm{CI}=0.02$ to $2.35 ; \mathrm{p}=0.045)$, strong husband support $(\mathrm{b}=1.24 ; 95 \% \mathrm{CI}=0.14$ to $2.39 ; \mathrm{p}=0.027)$, working outside the home $(\mathrm{b}=1.14 ; 95 \% \mathrm{CI}=0.06$ to $2.21 ; \mathrm{p}=0.037)$, number of children alive $\geq 3$ $(\mathrm{b}=1.74 ; 95 \% \mathrm{CI}=0.61$ to $2.88 ; \mathrm{p}=0.003)$, and maternal age $\geq 35$ years $(\mathrm{b}=1.57 ; 95 \% \mathrm{CI}=0.34$ to $2.75 ; \mathrm{p}=0.012)$. It was indirectly associated with age and education.

Conclusions: The choice of female surgery contraception method is directly and positively associated with good knowledge, positive attitude, good gender equality perception, high self efficacy, high education, strong husband support, working outside the home, number of children alive $\geq 3$, and maternal age $\geq 35$ years. It is indirectly associated with age and education.
\end{abstract}

Keywords: female surgery contraceptive method, determinant, path analysis

\section{Correspondence:}

Ainul Maghfiroh. Masters Program in Public Health, Universitas Sebelas Maret. Jl. Ir. Sutami 36A, Surakarta, Central Java 57126, Indonesia. Email: Ainulmaghfiroho504@gmail.com.

Mobile: +6285641012090.

\section{BACKGROUND}

Indonesia is one of the developing countries with a high rate of population growth, this is followed by problems related to reproductive health, namely the still high maternal mortality rate (MMR) which reaches 305 per 100,000 live births. The government establishes a Family Planning program especially for women of childbearing age in overcoming this problem with the use of contraception, one effective contraception with a low rate of failure compared to other methods is a permanent female method of contraception (Medforth et al., 2013; Kemenkes 2017) .

Female surgery contraception method (also called tubectomy) is the second closure of the tube so that the egg cannot be with sperm cells, the chances of a pregnancy are very small, with the advantage of 
not disturbing female hormones, not disrupting the menstrual cycle, not reducing sexual drive in women, and effective immediately, but based on the data taken by researchers the coverage of contraception is very low, which means that interest is also very low (Purwoastuti and Walyani, 2015).

Data from UNFPA (United Nations Fund for Population Activities) in 2016 showed that MOW contraceptive users accounted for $18.3 \%$ of $88 \%$ of all users of contraception. In Indonesia (2017), the number of active family planning participants is $62.39 \%$ and only $2.8 \%$ of them who are using MOW contraception. In Central Java (2017), only 3.6\% of MOW contraceptive participants are from $64.60 \%$ of all active family planning participants and in Kendal District in 2017, there are 3.7\% of $68.7 \%$ of all active KB participants (Ministry of Health, 2017; Central Java Health Office 2016, DP2KBP3A, 2018).

The determinants of MOW contraceptive use include age, education, occupation, number of living children, knowledge, attitude, husband support, self-efficacy, and gender perception. Age has a connection with someone in choosing contraceptive goals, namely preventing, narrowing or stopping pregnancy, women over the age of 35 prefer to stop pregnancy by long-term contraceptive methods. Education influences a person in accepting information and ideas, sufficient knowledge will motivate individuals to behave in a healthy manner. Knowledge will also influence one's attitude in taking action, in some studies attitudes positively influence contraceptive use. Women from rich households were more likely to use permanent contraceptive methods compared to women with middle or poor households. Job factors also determine in decision making where working women will be more concerned with managing when to get preg- nant and how many children they want. The results showed that mothers with more than 3 children and still living were three times more likely to have intention to undergo sterilization compared to mothers with less than three surviving children (Motumbo et al., 2014; Zenebe et al., 2017; Arifiana et al., 2018).

The Family Planning Program is one form of gender injustice where the goal of contraception aims at women more than men. Women bear a double burden compared to men, namely productive and reproductive roles, husband involvement in family planning decision-making processes is still lacking because they think that family planning is a wife's affair, this assumption is a form of gender-biased stereotypes, there are even couples who do not want to know partner's (contraceptive) contraceptive use, women are also responsible for contraceptive selection decisions by bearing the complications and side effects of the contraception, but the results of other studies state that there is still husband support as much as $67.4 \%$ of family planning decisions are carried out together, this implies that there is still good support from husband to wife, husband's support in the form of emotional support, financial information and instrumental support (Kurniawati, 2011; Fitriyani, 2016; Eshete and Adissu, 2017).

Determinants of contraceptive use for female surgery methods are important to study because of their effectiveness in suppressing population problems, reducing maternal mortality, but having low coverage compared to other contraceptives, and their permanent nature requires consideration and cooperation between husband and wife. This study employs path analysis to determine the direct and indirect relationship of determinants of female surgery contraceptive method use. 
Journal of Maternal and Child Health (2019), 4(3): 146-157

https://doi.org/10.26911/thejmch.2019.04.03.02

\section{SUBJECTS AND METHOD \\ 1. Study Design \\ This was a case control study conducted in South Kaliwungu, Kaliwungu, and Ngampel Districts, from October to November 2018.}

\section{Population and Samples}

The case population in this study was a contraceptive acceptor for female surgery methods with a total of 50 cases. The control group was contraceptive acceptors in addition to the female surgery method which amounted to 150 cases using the fixed disease sampling technique.

\section{Study Variables}

The dependent variable was female surgery contraceptive method use. The independent variables were maternal age, education, number of living children, employent, husband support, knowledge, attitude, selfefficacy, and perception of gender equality.

\section{Operational Definition of Variables}

Female surgery contraceptive method use was defined as maternal decision to choose the desired contraception from a variety of contraceptive options.

Education refers to the highest formal educational level pursued by mothers starting from elementary, junior high school, senior high school, and college.

Age was defined as how long the subjects have lived since birth to the time of the study of mothers who use contraception being selected. The measurement scale was continuous and transformed into dichotomous, coded o for $<35$ years old and 1 for $\geq 35$ years old.

The number of living children is the number of children who are still alive until the time the study was conducted from fertile couples who were married legally by law and religion. The data were collected by questionnaire. The measurement scale was continuous and transformed into dichotomous, coded o for $<3$ and 1 for $\geq 3$.
Occupation was defined as the main activity carried out by humans to meet their daily needs to earn a living or make a living for the community. The data were collected by questionnaire. The measurement scale was categorical, coded o for working at home and 1 for working outside the home.

Knowledge was the result of "knowing" and this happens after people have sensed a certain object. This sensation occurs through the five human senses, namely vision, hearing, smell, taste and touch with itself. It was measured by questionnaire. The measurement scale was continuous and transformed into dichotomous, coded o for o low and 1 for high.

Attitude was defined as a group of feelings, beliefs and responses of mother in the form of positive or negative judgments that affect mothers in using female surgery contraception method. The data were collected by questionnaire. The measurement scale was continuous and transformed into dichotomous, coded o for negative attitude and 1 for positive attitude.

Self-efficacy was defined as maternal belief for their ability to overcome the situation and produce useful things. Mothers with high self-efficacy will face challenges that must be mastered as threats to be avoided, the higher self-efficacy, the more achievement levels that can be realized. It was measured by questionnaire. The measurement scale was continuous and transformed into dichotomous, coded o for low and 1 for high self efficacy.

Husband support was defined as the support that the husband has given to his wife in relation to the use of contraception which includes emotional, informational, financial, and instrumental supports. It was measured by questionnaire. The measurement scale was continuous and transformed into dichotomous, coded o for weak and 1 for strong support. 
Perception of gender equity was someone opinion on gender equality which leads to the characteristics of socially constructed women and men such as the norms, roles and relationships that exist between them. It was measured by questionnaire. The measurement scale was continuous and transformed into dichotomous, coded o for poor and 1 for good perception on gender equity.

\section{Data Analysis}

The data were analyzed by path analysis run on Stata 13. Path analysis was conducted to examine direct and indirect effects on the determinants of the choice of female surgical contraceptive method.

\section{Research Ethics}

The research ethics include anonymity, confidentiality, and ethical clearance. The ethical clearance was obtained from Research Ethics Committee, Faculty of Medicine, Universitas Sebelas Maret, Surakarta, Central Java, with Number: 297/ UN27.6 / KEPK / 2018.

\section{Univariate Analysis}

Table 1 showed the results of univariate analysis. Table 1 showed that maternal age $<35$ years old was 110 (55\%). As many as 121 mothers (60.5\%) had education level $<$ senior high school. As many as 110 mothers (55\%) had good knowledge. Number of children alive <3 was 112 (56\%). As many as 114 mothers (57\%) had negative attitude toward female surgery contraceptive method. As many as 127 mothers (63.5\%) received weak husband support. As many as 103 mothers (51.5\%) had strong self-efficacy. As many as 113 mothers (56.5\%) had good perception on gender equity.

\begin{tabular}{|c|c|c|}
\hline Variable & $\mathbf{n}$ & $\%$ \\
\hline \multicolumn{3}{|l|}{$\begin{array}{l}\text { Female surgery contra- } \\
\text { ceptive method }\end{array}$} \\
\hline No & 150 & 75.0 \\
\hline Yes & 50 & 25.0 \\
\hline \multicolumn{3}{|l|}{ Maternal Age } \\
\hline$<35$ years & 110 & 55.0 \\
\hline$\geq 35$ years & 90 & 45.0 \\
\hline \multicolumn{3}{|l|}{ Education } \\
\hline$<$ Senior high school & 121 & 60.5 \\
\hline$\geq$ Senior high school & 79 & 39.5 \\
\hline \multicolumn{3}{|l|}{ Occupation } \\
\hline Working at home & 105 & 52.5 \\
\hline Working outside the home & 95 & $47 \cdot 5$ \\
\hline \multicolumn{3}{|l|}{ Number of children alive } \\
\hline$<3$ & 112 & 56.0 \\
\hline$\geq 3$ & 88 & 44.0 \\
\hline \multicolumn{3}{|l|}{ Knowledge } \\
\hline $\begin{array}{l}\text { Low } \\
\text { High }\end{array}$ & $\begin{array}{c}110 \\
90\end{array}$ & $\begin{array}{l}55.0 \\
45.0\end{array}$ \\
\hline \multicolumn{3}{|l|}{ Attitude } \\
\hline Negative & 114 & 57.0 \\
\hline Positive & 86 & 43.0 \\
\hline \multicolumn{3}{|l|}{ Husband support } \\
\hline Weak & 127 & 63.5 \\
\hline Strong & 73 & 36.5 \\
\hline \multicolumn{3}{|l|}{ Self-Efficacy } \\
\hline Low & 103 & 51.5 \\
\hline High & 97 & 48.5 \\
\hline \multicolumn{3}{|l|}{$\begin{array}{l}\text { Perception of gender } \\
\text { equity }\end{array}$} \\
\hline Poor & 113 & 56.5 \\
\hline Good & 87 & 43.5 \\
\hline
\end{tabular}

\section{Bivariate Analysis}

Table 2 showed the results of bivariate analysis on the determinants of female surgery contraceptive use. Table 2 showed that there was a significant relationship between maternal age $(\mathrm{OR}=5.2 ; 95 \% \mathrm{CI}=$ 2.54 to $10.64 ; \mathrm{p}<0.001)$, education $(\mathrm{OR}=$ $5.62 ; 95 \% \mathrm{CI}=2.79$ to $11.31 ; \mathrm{p}<0.001)$, working outside the house $(\mathrm{OR}=3.10 ; 95 \%$ $\mathrm{CI}=1.57$ to $1.60 ; \mathrm{p}<0.001)$, number of children alive $>3(\mathrm{OR}=8.50 ; 95 \% \mathrm{CI}=3.92$ to 18.41; $\mathrm{p}<0.001$ ), good knowledge ( $\mathrm{OR}=5.96$; 95\% $\mathrm{CI}=2.87$ to $12.39 ; \mathrm{p}<0.001)$, positive attitude (OR $=7.77 ; 95 \% \mathrm{CI}=3.66$ to 16.49 ; $\mathrm{p}<0.001)$, strong husband support $(\mathrm{OR}=$ $2.65 ; 95 \% \mathrm{CI}=1.37$ to $2.66 ; \mathrm{p}=0.004)$, self- 
efficacy $(\mathrm{OR}=5.62 ; 95 \% \mathrm{CI}=2.66$ to 11.58 ; $\mathrm{p}<0.001$ ), and good perception of gender p<0.001) on female surgery contraceptive equity $(\mathrm{OR}=3.45 ; 95 \% \mathrm{CI}=1.76$ to 6.76 ; method use.

Table 2. Bivariate analysis on the determinants of female surgery contraceptive use

\begin{tabular}{|c|c|c|c|c|c|c|c|c|c|}
\hline \multirow{3}{*}{$\begin{array}{c}\text { Independent } \\
\text { Variables }\end{array}$} & \multicolumn{4}{|c|}{$\begin{array}{c}\text { Female surgery } \\
\text { contraceptive method }\end{array}$} & \multirow{2}{*}{\multicolumn{2}{|c|}{ Total }} & \multirow[t]{3}{*}{$\mathbf{O R}$} & \multirow{3}{*}{$\begin{array}{c}95 \% \\
\text { CI }\end{array}$} & \multirow{3}{*}{$\mathbf{p}$} \\
\hline & \multicolumn{2}{|c|}{ No } & \multicolumn{2}{|c|}{ Yes } & & & & & \\
\hline & $n=150$ & $\%$ & $n=50$ & $\%$ & $\mathbf{n}=\mathbf{2 0 0}$ & $\%$ & & & \\
\hline Maternal age & & & & & & & & 2.54 & \\
\hline$<35$ years & 97 & 48.5 & 13 & 6.5 & 110 & 55.0 & & to & \\
\hline$\geq 35$ years & 53 & 26.5 & 37 & 18.5 & 90 & 45.0 & 5.20 & 10.64 & $<0.001$ \\
\hline $\begin{array}{l}\text { Number of } \\
\text { children alive }\end{array}$ & & & & & & & & 3.92 & \\
\hline$<3$ & 102 & 51.0 & 10 & 5.0 & 112 & 56.0 & 850 & $\begin{array}{l}\text { to } \\
1811\end{array}$ & $<0001$ \\
\hline $\begin{array}{l}\geq 3 \\
\text { Occupation }\end{array}$ & 48 & 24.0 & 40 & 20.0 & 88 & 44.0 & 8.50 & & $<0.001$ \\
\hline Working at home & 89 & 44.5 & 16 & 8.0 & 105 & 52.5 & & 1.57 to & \\
\hline $\begin{array}{l}\text { Working outside the } \\
\text { home }\end{array}$ & 61 & 30.5 & 34 & 17.0 & 95 & 47.5 & 3.10 & 6.10 & 0.001 \\
\hline Education & & & & & & & & & \\
\hline$<$ Senior high school & 106 & 53.0 & 15 & $7 \cdot 5$ & 121 & 60.5 & & 2.79 & \\
\hline$\geq$ Senior high school & 44 & 22.0 & 35 & 17.5 & 79 & 39.5 & 5.62 & 11.31 & $<0.001$ \\
\hline Knowledge & & & & & & & & 2.87 & \\
\hline Poor & 98 & 49.0 & 12 & 6.0 & 110 & 55.0 & 5.96 & to & $<0.001$ \\
\hline Good & 52 & 26.0 & 38 & 19.0 & 90 & 45.0 & $5 \cdot 90$ & 12.39 & $<0.001$ \\
\hline $\begin{array}{l}\text { Husband Support } \\
\text { Poor }\end{array}$ & & & & & & & & 1.37 to & \\
\hline $\begin{array}{l}\text { Poor } \\
\text { Strong }\end{array}$ & $\begin{array}{c}104 \\
46\end{array}$ & $\begin{array}{l}52.0 \\
23.0\end{array}$ & $\begin{array}{l}23 \\
27\end{array}$ & $\begin{array}{l}11.5 \\
13.5\end{array}$ & $\begin{array}{c}127 \\
73\end{array}$ & $\begin{array}{l}63.5 \\
36.5\end{array}$ & 2.65 & 5.11 & 0.004 \\
\hline Self-Efficacy & & & & & & & & 2.66 & \\
\hline Low & 92 & 46.0 & 11 & $5 \cdot 5$ & 103 & 51.5 & & to & \\
\hline High & 58 & 29.0 & 39 & 19.5 & 97 & 48.5 & 5.62 & 11.85 & $<0.001$ \\
\hline Perception of & & & & & & & & & \\
\hline Gender Equity & & & & & & & & 1.76 to & \\
\hline Low & 96 & 48.0 & 17 & 8.5 & 113 & 56.5 & & 6.76 & \\
\hline High & 54 & 27.0 & 33 & 16.5 & 87 & 43.5 & 3,45 & & $<0.001$ \\
\hline Attitude & & & & & & & & 3.66 & \\
\hline Negative & 103 & 51.5 & 11 & 5.5 & 114 & 57.0 & & to & \\
\hline Positive & 47 & 23.5 & 39 & 19.5 & 86 & 43.0 & $7 \cdot 77$ & 16.49 & $<0.001$ \\
\hline
\end{tabular}

\section{Path Analysis}

Figure 1 depicted path analysis model. Table 3 showed the results of path analysis. Table 3 showed that female surgery contraceptive method use was directly affected by good knowledge $(\mathrm{b}=1.91 ; 95 \% \mathrm{CI}=0.80$ to 3.02 ; $\mathrm{p}=0.001)$, positive attitude $(\mathrm{b}=1.56 ; 95 \%$ $\mathrm{CI}=0.45$ to $2.66 ; \mathrm{p}=0.006$ ), perception of gender equality $(b=1.25 ; 95 \% \mathrm{CI}=0.18$ to 2.32; $\mathrm{p}=0.021)$, strong self-efficacy $(b=1.61$; $95 \% \mathrm{CI}=0.48$ to $2.74 ; \mathrm{p}=0.005$ ), high education $(b=1.18 ; 95 \% \mathrm{CI}=0.02$ to $2.35 ; \mathrm{p}=$
0.045), strong husband support $(b=1.24$; $95 \% \mathrm{CI}=0.14$ to $2.39 ; \mathrm{p}=0.027$ ), working outside the house $(b=1.14 ; 95 \% \mathrm{CI}=0.06$ to 2.21; $\mathrm{p}=0.037$ ), the number of child $\geq 3$ ( $b=$ $1.74 ; 95 \% \mathrm{CI}=0.61$ to 2.88 ; $\mathrm{p}=0.003$ ), maternal age $\geq 35$ years $(b=1.57 ; 95 \% \mathrm{CI}=0.34$ to 2.75; $\mathrm{p}=0.012$ ).

Female surgery contraceptive method use was indirectly affected by maternal age and education. Education increased good knowledge $(\mathrm{b}=0.63 ; 95 \% \mathrm{CI}=0.05$ to 1.20 ; $\mathrm{p}<0.001)$. Knowledge increased attitude $(\mathrm{b}=$ 
$0.6 ; 95 \% \mathrm{CI}=0.03$ to $1.17 ; \mathrm{p}=0.037)$

$1.06 ; 95 \% \mathrm{CI}=0.48$ to $1.65 ; \mathrm{p}<0.001)$.

Maternal age increased high education $(b=$

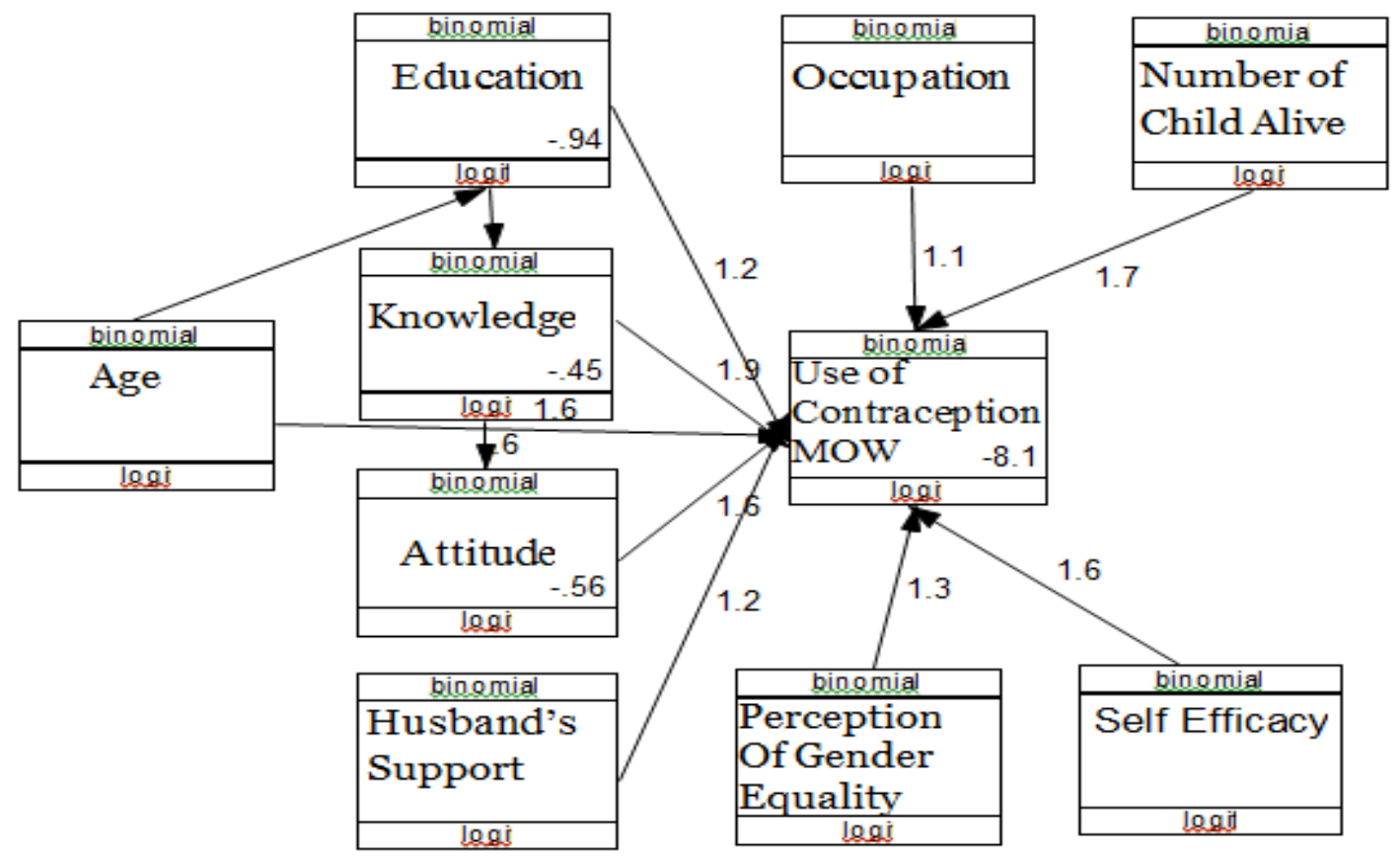

Figure 1. Path analysis model with estimation

Table 3. The results of path analysis

\begin{tabular}{|c|c|c|c|c|c|c|}
\hline \multirow{2}{*}{\multicolumn{2}{|c|}{ Dependent variable }} & \multirow[b]{2}{*}{ Independent Variable } & \multirow[b]{2}{*}{ b } & \multicolumn{2}{|c|}{$95 \%$ CI } & \multirow[b]{2}{*}{$\mathbf{p}$} \\
\hline & & & & Lower & Upper & \\
\hline \multicolumn{7}{|l|}{ Dirrect effect } \\
\hline Female surgery & $\leftarrow$ & Maternal age $\geq 35$ years & 1.57 & 0.34 & 2.75 & 0.012 \\
\hline \multirow[t]{8}{*}{ contraceptive use } & $\leftarrow$ & Number of children alive $\geq 3$ & 1.74 & 0.61 & 2.88 & 0.003 \\
\hline & $\leftarrow$ & High education & 1.18 & 0.02 & 2.35 & 0.045 \\
\hline & $\leftarrow$ & Good knowledge & 1.91 & 0.80 & 3.02 & 0.001 \\
\hline & $\leftarrow$ & Positive attitude & 1.56 & 0.45 & 2.66 & 0.006 \\
\hline & $\leftarrow$ & Perception of gender equality & 1.25 & 0.18 & 2.32 & 0.021 \\
\hline & $\leftarrow$ & Positive self-efficacy & 1.61 & 0.48 & 2.74 & 0.005 \\
\hline & $\leftarrow$ & Strong husband support & 1.24 & 0.14 & 2.39 & 0.027 \\
\hline & $\leftarrow$ & Working outside the house & 1.14 & 0.06 & 2.21 & 0.037 \\
\hline \multicolumn{7}{|l|}{ Indirect effect } \\
\hline Knowledge & $\leftarrow$ & Education & 0.63 & 0.05 & 1.20 & $<0.001$ \\
\hline Attitude & $\leftarrow$ & Knowledge & 1.21 & 0.62 & 1.81 & $<0.001$ \\
\hline Education & $\leftarrow$ & Maternal age & 0.63 & 0.48 & 1.65 & $<0.001$ \\
\hline
\end{tabular}

\section{DISCUSSION}

\section{Relationship between maternal age} and female surgery contraceptive use

The result of this study showed that there was a significant relationship between age and the use of women surgical contra- ceptive, women of reproductive age who were over or equal to 35 years old were1.57 times more likely to use women surgical contraceptive method compared to those under 35 years old, and age also indirectly influenced the use of women surgical contraceptive methods through education, 
where mothers who were over or equal to 35 years old were 0.63 time more likely to have higher education.

The result of the study about the relationship of age on the use of women surgical contraceptive was in accordance with this study, Mekonnen et al., (2014) stated that the 35-49 years old age group has a 6 times greater likelihood of using permanent contraception compared to the age group of less than 35 years old. The study by Kohls et al., (2017) also showed the similar idea, it was stated that the average age of women who did sterilization (tubectomy) was 40 years old, because mature women usually know the advantages, disadvantages, risks, and complications. This finding was in line with this study which showed that women who were over 35 years old were more likely to use WS contraceptive.

\section{The relationship between educa- tion and female surgery contra- ceptive use}

The result of this study showed that there was a direct and indirect relationship between education and the use of women surgical contraceptive. A direct relationship showed that high maternal education were 1.18 times more likely to use women surgical contraceptive compared to mothers with low level of education, while the indirect relationship showed that education has a significant relationship through knowledge, mothers who have high level of education were 0.63 time more likely to have good knowledge in using women surgical contraceptive.

The result of this study was in line with a study by Thulasedaran (2018) which stated that women with higher education prefer to use sterile contraception/women surgical methods compared to women with low level of education, Empowerment of women through the attainment of educa- tion and appropriate information about available contraceptive methods can gradually change the preference dominance for women-oriented permanent contraceptive methods.

\section{The relationship between number of children alive and female sur- gery contraceptive use}

The result of this study showed that there was a significant relationship between the number of children alive and the use of women surgical contraceptive. Mothers with more than 3 children alive were 1.74 times more likely to use women surgical contraceptive than to the number of children alive $<3$.

Mothers with more than 3 children have a high risk of pregnancy and childbirth, and were a threat to reproductive health and economic welfare, therefore, women should use permanent women surgical contraceptive method, limiting the number of children was intended to provide maternal health and giving better attention to the children, where the government also established a family planning program.

The result of a study by Dhungana et al., (2016) stated that the number of children has a significant effect on the use of contraception, the greater the number of children, the greater the interest in longterm contraceptive use. Female surgery contraceptive acceptors who have 3 children who were still alive tend to assume that the desired number of family members has been reached and in that condition, the age of the woman was more mature so that she thought more about family plans in the future so that effective and guaranteed contraceptive use prevented more selective pregnancy. The result of a study done by Fahim et al. (2017) was in line with the findings of this study which showed that the average number of children of 3 to 4 
influenced the decision of mothers to use WS contraceptive.

\section{The relationship between know- ledge and female surgery contra- ceptive use}

The result of this study showed that there was a significant relationship between knowledge and the use of women surgical contraceptive. Mothers with high knowledge were 1.91 time more likely to use women surgical contraceptive compared to mothers who have poor knowledge. High knowledge also has an indirect relationship with the use of women surgical contraceptive method through positive attitude, high knowledge would increase positive attitude on the use of women surgical contraceptive by 0,6 time.

The result of this study showed that there was a significant relationship between knowledge and the use of women surgical contraceptive $(p=0.001) .81 .5 \%$ of female surgery contraceptive users have good knowledge, knowledge that was received by acceptors would add more information related to contraception so that someone was more stable and confident about the decisions that have been taken by considering the effectiveness, side effects, safety, and comfort as well as in choosing a place of service because the knowledge was getting better. Information that was obtained by the mother through social media, neighbors, health personnels, or family planning service officers would generate new knowledge so that the transfer of information would change the behavior in using the contraception (Takele et al., 2012).

\section{The relationship between attitude and female surgery contraceptive use}

The result of this study showed that there was a direct and significant relationship between attitude and women surgery contraceptive use. Mothers with positive attitude were 1.56 times more likely to use women surgical contraceptive method than mothers who have negative attitude about women surgical contraceptive method. A positive attitude can be obtained through good knowledge.

The result of a study done by Arifiani et al., (2018) showed that there was an effect of attitude on the use of long-term contraception, mothers with positive attitude were 3.49 times more likely to use long-term contraception methods, one of them was women surgical contraceptive. Similar idea was stated Sundari et al., (2017) who stated that positive attitude also increased the use of long-term contraception, mothers with positive attitude were 4.02 times more likely to use long-term contraception.

A study done by Herlinawati et al., (2013) entitled factors related to contraceptive use in women surgery method showed that a positive attitude was related to the use of women surgical contraceptive method $(\mathrm{p}=0.016)$ compared to a negative attitude.

\section{The relationship between percep- tion of gender equality and female surgery contraceptive use}

The result of this study showed that there was asignificant relationship between perception of gender equality and the use of women surgical contraceptive. People who have a perception of gender equality were 1.25 time more likely to use women surgical contraceptive method than unequal gender perception.

Gender justice described the distribution between men and women from social and material resources and the power of decision making, according to the results of research done by Bentley and Kavanagh (2016), gender equality that occurred in society greatly gave a benefit for women 
Journal of Maternal and Child Health (2019), 4(3): 146-157

https://doi.org/10.26911/thejmch.2019.04.03.02

with low education in terms of increasing contraceptive use.

The government created more types of contraceptives for women so that women became tools to use a contraception. The role of family planning with gender justice was initiated by good communication between husband and wife to decide the one who would use the contraception and the type of contraception, the results of this study stated that most respondents did not experience gender discrimination in contraceptive use, however, respondents with low level of education were more likely to experienced gender discrimination compared to respondents with high level of education (Putri, 2014; Nuraini 2013).

\section{The relationship between self- efficacy and female surgery contra- ceptive use}

The result of this study showed that there was a significant relationship between selfefficacy and the use of women surgical contraceptive with path coefficient score of 1.61 and $\mathrm{p}=0.005$ which mean that mothers with high self-efficacy were 1.61 times more likely to use women surgical contraceptive method than mothers who have low self-efficacy to use women surgical contraceptive method.

Self-efficacy was part of social cognitive theory, self-efficacy was influenced by individual specific abilities and other individual factors, and also environmental factors that support or inhibit.

The result of this study was in line with a study done by Sundari et al, (2017) which stated that people who have high self-efficacy were 3.23 times more likely to use long-term contraception methods than people who have low self-efficacy which in this case was the use of women surgical contraceptive method.

\section{The relationship between husband support and female surgery contraceptive use}

The result of this study showed that there was a direct and significant relationship between husband support and the use of women surgical contraceptive. Mother who got strong husband support were 1.24 times more likely to use women surgical contraceptive method than mothers who got lack of husband support on the use of women surgical contraceptive method.

The result of this study was in line with a study done by Sufiati et al., 2013 which stated that husband support affected the mothers in making a decision to use women surgical contraceptive method, Husband support was a reinforcing factor that can affect the maternal behavior, husband support was very important in the use of contraception because it was a real form of husband's responsibility to his wife. Anguzu et al., 2014 stated that the approval of the partner would increase the use of long-term contraception methods, one of them was women surgical contraceptive.

The form of husband participation in family planning could be directly or indirectly. Directly, the husband could use the contraceptives for men such as condom use and the use of vasectomy contraception. The indirect support from husbands to their wives was by participating in choosing the contraception for their wives, participating in discussing the types of contraception which was suitable for their wives, reminding the wives to control and revisit, helping to find help if there were side effects or complications that occur in using the contraception, and financing the use of contraception.

The results of qualitative research by Karla et al. (2015) showed that wives tend to discuss and ask permission from husbands in deciding sterilization measures. If 
the husband was willing, the surgery can be done. These conditions were part of husband support for their wives in using female surgery contraceptive method.

\section{The relationship between employ- ment and female surgery contra- ceptive use}

The results of this study analyzed the relationship of maternal employment with the use of women surgical contraceptive method, most of the women who worked outside the house in the group of women surgical contraceptive users have a job as factory employees by 17 people (8.5\%). In the multivariate analysis, there was a significant relationship between occupation and the use of women surgical contraceptive, mothers who worked outside the house were 1.14 times more likely to use women surgical contraceptive method compared to housewives.

This result was strengthened by a study by Gebre-Egziabher et al., (2017) which stated that mothers who work outside the house were 2.37 times more likely to use long-term contraception methods, one of them was women surgical contraceptive method.

Employment in the broad meaning was the main activity conducted by humans to fulfill their daily needs to earn a living or make a living for the community. Women of reproductive age who did not work such as housewives tend to have more children, which was more than two children, low education was the reason to not get a job, women who work tend to use the contraception. Eventually, people who did not use a contraception must be prepared for the occurrence of pregnancy with the occurrence of physical and psychological changes (Hanifah et al., 2014; Saskara and Marhaeni, 2015).

\section{REFERENCE}

Anguzu R, Sekandi JN, Muhumuza C, Serwadda D, Tweheyo R, Zalwango V, Tusiime S (2014). Knowledge and attitudes towards use of long acting reversible contraceptives among of reproductive age in lubaga division, kampala distric, Uganda. BMC Research Notes, 7 (153). https://doi.org/ 10.1186/1756-0500-7-153

Arifiana R, Budihastuti UR, Qadrijati I (2018). Biopsychosocial determinants of long-term contraceptive use in women of reproductive age in Surakarta, Central Java. Journal of Health Promotion and Behavior, 3(1): 37-47. https://doi.org/10.26911/thejhpb.2018.03.01.03

Bentley R, Kavanagh AR (2016). Gender equity and women's contraception use. Australian Journal of Social Issue. 43(1); 65-80. https://doi.org/ 10.1002/j.1839-4655.2008.tbooo9o.x

BKKBN (2005). Peningkatan partisipasi pria dalam KB dan KR. Jakarta: BKKBN

Dhungana A, Nanthamongk S, Pitikultang S (2016). Factors related to intention to undergo female sterilization among married women in Rural Kathmandu, Nepal. Nepal journal Epidemiologi. 6(1): 539 .

Fahim MA, Ranjan DP, Namita (2017). A study on socio-demographic and cultural factors influencing women undergoing laparoscopic tubectomy in laparoscopic tubectomy camps conducted at UHTC, Aam Talaab, Raichur. Indian Journal of Forensic and Community Medicine, 4(1): 31-35. https://doi.org/10.18231/2394-6776 .2017 .0006

Fitriyani (2016). Peran perempuan dalam penggunaan alat kontrasepsi. Journal 
Masyarakat, Kebudayaan dan Politik. 29(3): 1-10.

Gebre-Egziabher D, Medhanyie AA, Alemayehu m, Tesfay FH (2017). Prefalence and Predictore of implanon utilization among women Reproductive age group in Tgray Region, Northern Ethipia. Reproductive Health, 11(24). https://dx.doi.org/10.1186/s12978017-0320-7

Hanifah, Asyik, Zulkarnaen (2014). Pengaruh pendidikan, pekerjaan, usia kawin pertama, penggunaan alat kontrasepsi terhadap jumlah anak. Jurnal Penelitian Geografi. 2(8); 1-10.

Herlinawati, Maya F, Santosa, Heru (2013). Faktor yang berhubungan dengan pemakaian kontrasepsi tubektomi pada pasangan usia subur di RSUD Dr. Pirngadi Medan. Gizi, Kesehatan Reproduksi dan Epidemiologi. 2(3). http://jurnal.usu.ac.id/index.php/gkr e/article/view/3642 .

Kemenkes RI (2017). Data dan Informasi Profil Kesehatan Indonesia 2016. Pusat Data Dan Informasi Kementrian Kesehatan 2017.

Kalra R, Phadnis S, Joshi A (2015). Perceptual analysis of women on tubectomy and other family planning services: a qualitative study. International Journal of Reproduction, Contraception, Obstetrics and Gynecology. 4(1):9499. https://.doi.org/10.5455/23201770. ijrcog20150218.

Kohls A, Kuehnle E, Brodowski L, Staboulidau I (2017). Female sterilization as a method of contra ception: women's acceptance and know ledge-a review. Medical Research Archives, 5(9).

Lakshmi SG, Radharani PA (2015). A study on Factors Influencing the choice of Permanent Method of Family Planning, 14(6): 16-22. https://doi.org /10.9790/0853-146516 22.
Medforth, Battersby, Evans, Marsh, Walker (2013). Oxford handbook of midwifery. EGC: Jakarta

Mutombo N, Bakibinga P (2014). The effect of joint contraceptive decisions on the use of Injectables, Long-Acting and Permanent Methods (ILAPMs) among married female (15-49) contraceptive users in Zambia: a cross-sectional study, Journal Reproductive Health 11(1): 1-8. https://doi: 10.1186/17424755-11-51.

Nuraini (2013). Keluarga berencana berkeadilan gender sebagai upaya pembentukan keluarga sakinah. https://digilib.uinsuka.ac.id/id/eprint/8546.

Pandey A, Singh KK (2015). Contraceptive use before first pregnancy by women in India (2005-2006): determinants and differentials. BMC Public Health; 15(13):16.

Putri CP (2014). Kesetaraan gender dalam program keluarga berencana di Dusun Sawahan Kabupaten Mojokerto. Repository Poltekkes Majapahit Open Journal System.

Saskara, Marhaeni (2015). Pengaruh faktor sosial ekonomi dan demografi terhadap penggunaan kontrasepsi di Denpasar. Jurnal Ekonomi kuantitatif Terapan.8(2): 155-161.

Sufiati F, Mardjan H, Saleh I (2014). Faktor-faktor yang berhubungan dengan pemakaian alat kontrasepsi tubektomi pada pasangan usia subur. Jurnal Mahasiswa dan Penelitian Kesehatan 2(1): 151-127.

Sundari A, Sulaiman E, Murti B (2018). Health promotion on the choice of long term contraception methode in Kendal, Central Java. Journal Promotion and health https://doi.org /10.26911/mid.icph.2018.02.05.

Takele A, Degu G, Yitayal M (2012) Demand for long acting and permanent 
methods of contraceptives and factors for non use among married women of Goba Town, Bale Zone, South East Ethiopia. Reproductive Health, 9(1): 11. http://dx.doi.org/10.1186/1742-4755-9-26.

Thulaseedharan JV (2018). Contraceptive use and preferences of young. Open Access Journal of Contraception. (9): 1-10.
Zenebe CB, Adefris M, Yenit MK, Gelaw YA (2017). Factors associated with utilization of long-acting and permanent contraceptive methods among women who have decided not to have more children in Gondar city. BMC Women's health. 17(75): 1-7 https://doi.org/10.1186/s12905-017-0432-9 